\title{
Critical practice leadership in post-compulsory education
}

\begin{abstract}
This article questions why leaders in post-compulsory education tend not to view leadership research positively or utilise it in improving their practice. Drawing on the theoretical literature of educational management and leadership, and the current political and economic context of post-compulsory education, it proposes a new direction of critical practice leadership informed by advanced practitioner research. Challenging assumptions about leadership practice and leadership research creates opportunity for an ethical and practical perspective for leadership practitioners, and a distinctive contribution to the field of leadership theory and research by resisting the false dualism between theory and practice.
\end{abstract}

\section{Key Words}

Post compulsory education, leadership, critical practice, research, ethics, values,

\section{Post-compulsory education, the market and the ethical turn}

Education should begin in research and end in research .... An education which does not begin by evoking initiative and end by encouraging it must be wrong. For its whole aim is the production of active wisdom (Whitehead, 1962, pp 57-8).

If education cannot do everything, there is something fundamental that it can do. In other words, if education is not the key to social transformation, neither is it simply meant to reproduce the dominant ideology.... The freedom that moves us, that makes us take risks, is being subjugated to a process of standardization of formulas, models against which we are evaluated. ... We are speaking of that invisible power of alienating domestication, which 
attains a degree of extraordinary efficiency in what I have been calling the bureaucratizing of the mind (Freire 1998: 110-11).

This opening section outlines the prevailing and persistent crisis in post-compulsory education and asks the question whether leaders must succumb to the influence of the market, or can show resistance. An ethical turn holds out a new direction away from the assumptive world that the field of leadership studies has long inhabited.

Post-compulsory education in England, embracing further and higher education, in common with other parts of the education system and more widely with the public sector as a whole, is in the middle of a crisis that has created conditions that have impacted hugely upon the way institutions are managed and led.

In higher education worldwide the trend towards mass participation, growth in private provision, student fees, competition and internationalisation have combined to lay the sector open to market influence as never before. In the UK, the dilution of a progressive planning and funding body (the Higher Educaton Funding Council for England), the sudden and marked increase in student fee contributions, and the introduction of the Student Control Number, have all contributed to 'the risk of market failure for institutions' (Smith 2013). As Barnett has argued, even the knowledge base that underpins universities' existence is now challenged, such that 'a new epistemology for the university awaits, one that is open, bold, engaging, accessible, and conscious of its own insecurity.... an epistemology for living amid uncertainty’ (Barnett 2000: 420).

In further education, as education and skills funding grants are ever more squeezed, vocational education remains a poor relation, and college mergers stand at an all time high, threatening to dissolve local provision and opportunity, the bedrock of the sector. In one sense, nothing much seems to have changed since 1985 when the sector was described as 'in the main one of fragmentation, confusion, complexity and competition' (Twyman 1985: 329-30). These persisitent trends raise an important question for educational managers, namely whether and how postcompulsory education organisations can be effectively led, changed and improved through an unstable, and many would argue turbulent, environment. 
In the face of seemingly constant capacity-limiting reform in education, now more than ever, it is vital to make an ethical turn in post-compulsory education that directs our attention to education's fundamental purposes (Hargreaves and Fink 2006, Elliott 2012). Education has at its core a moral purpose, to make a difference, to bring about improvements, to be transformational, therefore effective leadership practice in education is of necessity rooted in values (Sergiovanni 1992) - a practice that has been rightly described as a 'moral art' (Hodgkinson 1991), involving 'intuition as well as rational analysis' (Starkey and Madan 2001: 10), and with a 'moral dimension that distinguishes it from other types of influence, such as coercion or despotic control' (Northouse 2004). In the field of educational management, Bush (2011:pp. 1,2) has reminded us that the field 'should be centrally concerned with the purpose or aims of education' and that '(u)nless this link between purpose and management is clear and close, there is a danger of "managerialism", In persuading educators and those who lead them to think and act ethically in responding to policy directions, we might recall the advice of G.H Bantock $(1965,120)$, writing nearly half a century ago:

Because, as a matter of fact, certain changes take place in the social structure, the educator is not morally obliged to follow them unless he (sic) is persuaded, on grounds other than the fact of change, that these changes are for the good. The ethical proposition that all change is necessarily change in the direction of the good, is not one that human experience could in any way sustain.

Greenfield (1991: 208) is one of very few educational leadership scholars who has understood the interdependence of ethical and effective leadership, when he asserted that '(r)ationality to be rationality must stand upon a value base'. As Bush (2011: 186) notes:

Moral leadership is consistent with organizational culture in that it is based on the values, beliefs and attitudes of principals and other educational leaders. It focuses on the moral purpose of education, and on the behaviours to be expected of leaders operating in the moral domain. It also assumes that these values and beliefs coalesce into shared norms and meanings that either shape or reinforce culture. 
This last point is very important. The essence of ethical leadership goes further than an expression of the values and beliefs of the leader themselves - it extends to an institutional ethical direction and purpose, and the working through of this in terms of principles, procedures and actions that govern, shape, regulate and guide transactions, especially with external bodies, collaborators and partners.

The question of course arises, 'whose values?' There can be only passing comment on this here, however recognizing that the issue is of central importance to the present discussion. Values conversations are bound in time, place and circumstances, so a starting point that recognizes this contextual imperative is important. My proposition is that a base line for educational leaders should be primum nil nocere, or 'first, do no harm' - the principal precept of medical ethics worldwide. If post compulsory educational leaders had universally followed this principle there is no doubt that a number of opportunistic, profit inspired, high risk and disastrous mergers, acquisitions, and speculative investments, that have reduced rather than enhanced educational opportunity could have been avoided. A requirement or expectation for a leader to critically reflect upon their practice to make sure they are not the cause of the very problems they are trying to solve might in time foster ethical and sustainable educational leadership. To do no harm is a higher order imperative than doing good. The two don't necessarily go hand in hand - Kant (1997) would see doing no harm as a perfect duty (categorical) whereas doing good is an imperfect duty which cannot be absolute because it is not possible all the time.

It is frequently claimed that the values of those who lead inevitably complex further and higher education organisations become uncoupled from the values of the professionals and practitioners they manage. This is one of the most persistent dualities in the literature of educational management and leadership, between manager and professional, or leader and practitioner. A strong contributing factor to this duality seems to be the question of values. This uncoupling is felt to be a consequence of the competing priorities faced by leaders and managers, challenged by the complexity and pressing demands of a marketised educational environment, and perhaps forced to distance themselves by politically motivated decisions. As Esland (1996: 36) puts it:

It is in the nature of managerialism .... (t)hat managerial operations become separated from, and invariably take precedence over, those performed by professional employees. The centrality to the institution of financial control, public relations, marketing and income generation inevitably reorient its priorities and further exacerbate the central divide between 
managers and professionals .... 'strategic planning' becomes the dominant concern of the 'senior management team' while the former mainstream tasks of teaching become subordinated to the structures emerging from its decisions.

Opinion seems divided in the literature on the extent to which practitioners in post-compulsory education can avoid or overcome such market pressures. This is a crucial issue for leaders in post-compulsory education, including distributed 'middle' leadership in colleges and universities where professionals/practitioners are also leaders in their own right, since it defines their scope, capacity and will to bring about change and improvement, or the extent to which they can overcome the bureaucratising of the mind of which Freire (1998) wrote.

Many scholars follow Ball (2007: 186) in asserting that 'it is economism which defines the purpose and potential of education', and argue that managerialism is universal and irresistable in post-compulsory education (eg Randle and Brady 1997, Gleeson and Shain 1999, Lumby and Tomlinson 2000, Deem, Hillyard and Reed 2007). Elliott's (1996) study of further education lecturers in the period following incorporation, on the other hand, found that they 'could draw upon a repertoire of strategies to thwart attempts to impose external systemic and specific changes that they perceived to be at variance with their core values' (1996: 7). Similarly, Strain (2009) recognises the challenges that teachers and others occupying leadership positions in education face working in such a context, citing Moore et al's (2002) subverting response of strategic pragmatism:

Typically, this involves the conscious practice of creative, sometimes subversive responses to reform, and to the effects of reform, with each issue being carefully measured and judged in terms of what is and what is not acceptable, set against the institution's espoused philosophy and practice. Such a response, rather than being configured in terms of submission to dominant but unacceptable ideologies, could be configured alternatively as self-actualizing, emancipatory, and the best safeguard of professional and institutional health in times of extensive policy change....Strategic pragmatism embodied in performative practices holds out opportunities reflexively to reconstitute current education policies and practices on radically different ethical principles, within educational communities of friends (Strain 2009: 81). 
We can see beginning to emerge in the theoretical literature (eg Fullan 2005, Hargreaves and Fink 2006, Strain 2009) a call to build agency and ethicality into leadership education and practice. Business Schools for many years inhabited, and to a degree helped to create, an amoral universe of corporate greed, exemplified in the corporate scandals such as Enron and Tyco that rocked the western financial world in the 1990s. As Sumantra $(2005: 75,76)$ noted, '(o)ur theories and ideas have done much to strengthen the management practices that we are now all so loudly condemning.... (and) by propagating ideologically inspired amoral theories, business schools have actively freed their students from any sense of moral responsibility'. Interestingly, he locates the root of this malaise in business and management education in its construction of theory that is predominantly causal or functional, leaving no room for ethics or morality, which are mental phenomena. In other words, research in the field has adopted 'a naïve and unreflecting empiricism' (Whiltley 1984: 387). This determinist direction has been necessary to validate the claim of the field to be a science, with the tragic consequence that when leaders 'claim that competition or capital markets are relentless in their demands, and that individual companies and managers have no scope for choices, it is on the strength of the false premise of determinism that they free themselves from any sense of moral or ethical responsibility for their actions.' (Whiltley 1984: 77)

Bourdieu (1990) is helpful in this context, and provides a useful theoretical framework from which we, as practising leaders in post-compulsory education, might break out of this assumptive world and develop leadership research that embodies technical, illuminative, critical, practical, positional and moral dimensions of knowledge.

As Lingard and Christie highlight (2003: 319-20):

It is our contention that Bourdieu's concepts of 'habitus' and 'field', when developed in the context of leadership studies, enable us to move beyond trait, situational and transformational leadership theories, emphasizing instead the recursive relationship between agency (individual leader habitus) and structure (field) in the broader social context. Habitus enables us to talk about the person of the leader not simply in terms of traits, character and personal influence, but also in relation to specific social structures and embodied dispositions. Field enables us to talk about the context of leadership, in this case the school, as 'structured social space' with its 
own properties and power relations, overlapping and interrelating with economic, power, political and other fields.

In a similar vein, Dempster (2009: 20-21) argues that leadership in education must combine the key elements of context, human agency and purpose, and that '(c)ritical to keeping moral purpose centre stage is an understanding of the primacy of the learning needs, interests, abilities and aspirations of children, young people or adult learners, in fact all who at one time work with teachers or those in leadership positions.' This illustrates well the danger that if the educational community does not get involved in developing good educational practice of management then there will be a vacuum which can exploited by any view. We may end up arguing that anything goes (Feyrabend 1975).

It is the twin elements of individual agency (the capacity of educational leaders to choose to resist market forces) together with moral purpose (the ethical aims of education) that have been missing from educational leadership and leadership research. The question of individual agency, or in our context the ability of leaders to break out of channelled thinking and enacting, is a crucial one for leadership studies. In order for a leader to think of acting ethically, there has to be a connection between the ability to make a thoughtful considered strategic decision and the ability to think and act ethically - the two are inextricably intertwined. I return to this in the final section in the context of critical practice leadership.

The rest of this article explores how this position has come about and how leaders, supported by research, might break out of such a sterile envelope.

\section{The field of leadership research}

This section explores the knowledge base of leadership research and argues that if research is to be both valuable to and valued by managers it must address impact, influence and credibility, and embrace the challenge and criticality that has been absent from much work in the field. 
There are many ideas about research, what it is, and what it should be. Researchers themselves disagree about the validity of different research methodologies, and there is deep scepticism about whether practitioner research in particluar can illuminate complex educational problems (Tooley and Darby 1998, Cochrane-Smith and Lytle 1998). Gorard (2005), for example, urges that we resist the "pretence that the reflexivity of practitioners is somehow the same as research" (2005:159) and argues that research in the field of leadership and management has a serious problem, being mainly qualitative, small scale, and substantially non-empirical,'very inward-looking, apparently unwilling to test the impact of leadership on anything but management itself' $(2005: 158)$. This view is endorsed by Foskett et al (2005: 246) who note that 'it is rare for ELM [educational leadership and management] researchers to engage in multi-disciplinary work, for example with those in other social sciences, in management, in psychology or in statistics.'

Lawrence Stenhouse (1975), on the other hand, was a lifelong and passionate advocate of practitioner research by teachers, the idea of the teacher as an extended professional and the goal of 'autonomous professional selfdevelopment through systematic self-study, through the study of the work of other teachers and through the testing of ideas by the classroom research procedure' (Stenhouse 1975:144). Elliott and Crossley (1994: 196) extend this argument to managers in post compulsory education, arguing that 'qualitative research and evaluation, combined with the practitioner research model, can provide the educational manager with a highly effective management tool that is more sensitive to the perspectives of those directly involved in the teaching and learning process.' Coleman (2007: 479) concurs that leaders as researchers need 'to explore the value of practitioner-based enquiry in bridging the gap between leadership research and leadership practice, at the individual, organizational and system levels.' Scholars therefgore appear divided on whether practitioner research can be a powerful empowering mode of research in educational leadership and management contexts (Greenfield 1993), one that amounts to 'a new paradigm that aims to frontally transform rather than describe a school or classroom setting' (Cochrane-Smith and Lytle 1998: 31).

There does, though, seem to be widespeard agreement on the need to transform the knowledge base for educational leadership and management, to 'seek progress via the elimination of plausible explanations, by greater use of parsimony and transparency, and by challenging our own beliefs and testing our theories - even to destruction' 
(Gorard 2005: 162) echoing Shavelson et al (2003, cited in Gorard (2005: 160) who insist that good research should be 'disclosed to critique, rather than playing only to a gallery of existing converts'.

An important issue for us in understanding the power and limitation of leadership research as a strand of the field of management studies is the elusive character of discussions about organisational management. Certainly, organisational management is a key aspect of post compulsory education as self-evidently a great part of the latter takes place in an organisation of some sort. As illustrated above, many studies fall into sterotypical generalisation at one pole or dogmatic singularity at the other. In practice, however, organisational reality is more complex than such characterisations suggest, embracing ambiguity, power, fragmentation and chaos (Mintzberg 1975, Weick 1979, Jackall 1988, Watson 1994).

The significance of this simple insight cannot be overestimated. In too many studies it is the assumptive world of the researcher that is laid before us, rather than the actuality of participants' lived experiences. Of course, there is no less an issue when the researcher is exploring their own experience, where the challenge is to position their own world as anthropologically strange (Garfinkel 1984 [1967]). The implications of this for management and leadership research are nicely summarised by Alvesson and Deetz (2000: 114):

Taking the interpretive nature of research seriously means that one avoids prematurely applying conventional ideas and words such as leader and leadership (and manager and management, man and woman, strategy, culture, etc. for that matter). These interpretations - it is seldom self-evident that a person, a behaviour or a relationship are best conceptualized in these terms - must be applied with care. To continue with the example of leadership, the degree of assymmetry of a specific relation - normally seen as a major criterion for talk about leadership - may be ambiguous, inconsistent, contradictory and even transcend formal relations (as when a former subordinate has a larger impact on a superior than the other way around).

In reviewing the poor performance of management theory in improving business and educational organisations, Fullan (1998: 7) concludes that in light of the complexity of each organisation's unique personalities and cultural conditions there is no silver bullet, and suggests: 
Instead of hoping that the latest technique will at last provide the answer, we approach the situation differently. Leaders for change get involved as learners in real reform situations. They craft their own theories of change, consistently testing them against new situations. They become critical consumers of management theories, able to sort out promising ideas from empty ones. They become less vulnerable to and less dependent on external answers. They stop looking for solutions in the wrong places.

Wheatley $(1994,7)$ brings a similar perspective to her work on leadership, arguing that no organisation 'can be changed by imposing a model developed elsewhere' and that 'there is no objective reality out there waiting to reveal its secrets'. These scholars' insightful contribution to our thinking on leading educational change is to pull our gaze away from seductive leadership and management theories as if they can be transplanted straightforwardly into universities, colleges and schools. They remind us that leaders must lead, and that in order to do it well, they must imagine, innovate, think out of the box.

It is an open question to what extent leaders either use the results of research in reaching management decisions (research in use), or carry out their own research to investigate workplace problems (research in action). Although Gill and Johnson (1997: 161-2) argue that management research is held to be 'useful not only in itself in substantive problem solving but also, through the process of engagement in research, as a means of management development'.

Foskett et al (2005: 247) claim that '(t)he extent to which practitioners are consumers of education leadership and management research is still questionable' citing Galton's (2000) survey of schools which found that in terms of influencing senior managers' practice, only a very small minority of educational leadership and management research was found to be influential. Although managers constitute a group with a legitimate interest in management knowledge (Alvesson and Deetz 2000: 8) there is relatively little attention paid in the literature to the barriers to research influence on management practice. Schon's (1983: 264-5) work is often cited in support of the view that managers do engage in research as part of their management toolbox:

It is clear that managers do sometimes reflect in action. Beginning with questions like, What do customers really see in our product? What's really going on underneath the signs of trouble in 
our organisation? Or, what can we learn from our encounters with the competition? Managers try to make sense of the unique phenomena before them. They surface and question their intuitive understanding and in order to test their interpretations they undertake on-the-spot experiments. Not infrequently, their experiments yield surprising results that cause them to reformulate their questions. They engage in reflective conversations with their situation.

However, we need to question exactly how close are assessing realistic options for action on the one hand, and action research or reflective practice, in the systematic quasi-experimental manner of Schon's model, on the other hand. There is little evidence to support the view that managers routinely or even occasionally use research beyond participation in academic study or in career management development programmes. In Bennett and Gill's (1978) study of practising managers, research was regarded as something done by academics, remote from management culture, lacking credibility, not cost effective, and largely irrelevant to the problems they faced. As Baldwin et al's (2011: 587) critique of management education shows, it frequently does not prepare managers to know when and where to take appropriate action, or what they term as knowing to, 'having access to one's knowledge in the moment-knowing to do something when it is needed.' This is often colloquially referred to as the inability to act in the moment or to do it when it counts.

Research in the field of education has had an equally torrid time. Over the last 20 years or so, especially in the UK, educational research has struggled to win over a sceptical audience, that has questioned its relevance, scholarship, methodology, value and authority (Tooley and Darby 1998). Finch (1986) has highlighted a disjuncture between theoretical work, educational research findings and policy formulation, however, as Crossley and Hall (1994: 5) have pointed out, 'the importance of research training for educational managers and administrators is nevertheless increasingly recognised at home and abroad.'

Hargreaves (1996: 6) has led calls for bringing research closer to practitioners, urging 'the involvement of user communities, policy makers and practitioners, in all aspects of the research process'. It is a model of collaborative research that is being advocated here, which is qualitatively different from research co-operation, or simply involving participants in some aspects of the research process (Costley et al 2010). 
Hutchinson (1998: 380) in a study of why managers paradoxically do not pursue action research in their practice, whereas they have been enthusiastic about it in their taught CPD, points to the importance of recognising that some forms of research may carry favour within a managerialist paradigm, whilst others may be deemed of lower value:

Positivistic kinds of research... in the past have not, because of their reductionist, fragmenting and instrumental nature, been of much value to educational practitioners. Management research-practice conceived in this perspective necessarily carries an authoritarian and coercive element. To the extent that action research claims to promote democratic and egalitarian educational values, it constitutes the antithesis of managerialism and therefore could expect to receive a hostile reception in this type of environment.

This contributes to a range of evidence to suggest that amongst some managers there is 'a deep-seated unease about data that is seen as subjective ... (that) appears to be the legacy of a culture and education system that accords the objective scientific approach the highest status' (Skinner, Tagg and Holloway 2004: 400).

Hutchinson locates the source of the problem in the undemocratic conditions which typify bureaucratic structures. His analysis, although somewhat determinstic, is however partly optimistic, since he cites Halliday (1996) and Hutchinson $(1995,1996)$ in claiming that there is evidence that in various policy market led initiatives there is similar space to that located in his own case study for the recreation of educational as opposed to managerialist values and practices, echoing Elliott's (1996: 7) observation cited above that lecturers could assert their own values in the face of managerialism.

Whilst there is widespread agreement in the research literature that effective strategic leadership requires the capacity to learn and to change (Boal and Hooijberg 2001, Gill 2002, Day et al 2001) it is more than possible that managers are genuinely confused about the relationship of theoretical work and research findings to their practice. This confusion may have its origins in a management education tradition which conceives management as a purely technical activity (McIntyre 1981) that is morally and politically neutral. The negative positioning of research into leadership and management may be both initiated and reinforced through managerialist perspectives on management education, ie the view that management education stands in a functional relationship to management itself: to improve organisational effectiveness and individual manager performance. 
Such a view sets up an opposition between theory and practice that is as incoherent as it is confusing (Grey and Mitev 2004), since all practice is informed by some theorising, as much as all theories are testable in practice. This duality is quite persistent and is embedded in Gibbons et al's (1994) formulation of knowledge modes as either Mode 1 (disciplinary, located in universities) or Mode 2 (applied, located in the 'real world'). Grey's (2001: S28) critique of this position is well made, rejecting the false duality that underpins such a crude distinction between situated knowledge modes:

This account posits the traditional university as a more-or-less ivory tower, detached from practical concerns and immune from external criticism. The problem with this claim is that it is inattentive to the historical nature of universities, which have always exhibited both - if we must use these terms - M1K and M2K attributes. Universities have always been fundamentally and deliberately associated with the production of socially useful knowledge: it is hard to envisage industrial, social and technological development without the scientific and social scientific underpinning of university research.

As Lewin (1952: 169) has observed ' $(t)$ here is nothing more practical than a good theory'. As a result, it is not surprising that when a manager tries to apply a management technique or approach or theory that has been learned as a prescriptive tool for business improvement, and it fails because account has not been taken of the complexity of the context, the manager may not make the attempt again and may become negative and suspicious about learned approaches, techniques and theories (Elliott 1991). S/he may in future reject research, theory, alternative possibilities, on the grounds that these have in the past been found not to fit some partial notion of the world out there that is somehow separate from theoretical formulation and change focused perspectives.

\section{Leadership of learning: critical practice leadership}

This final section draws on a range of literature to elaborate a more promising direction for leadership that is characterized by leadership of learning, critique and explicit moral principles. 
If educational leaders in post compulsory education are to be supported by a research literature that is credible, critical, ethical and useful, it is going to be essential to reconnect theory and practice, and begin to build an alternative that is informed by a different philosophical position. As Grey and Mitev (2004: 152) put it:

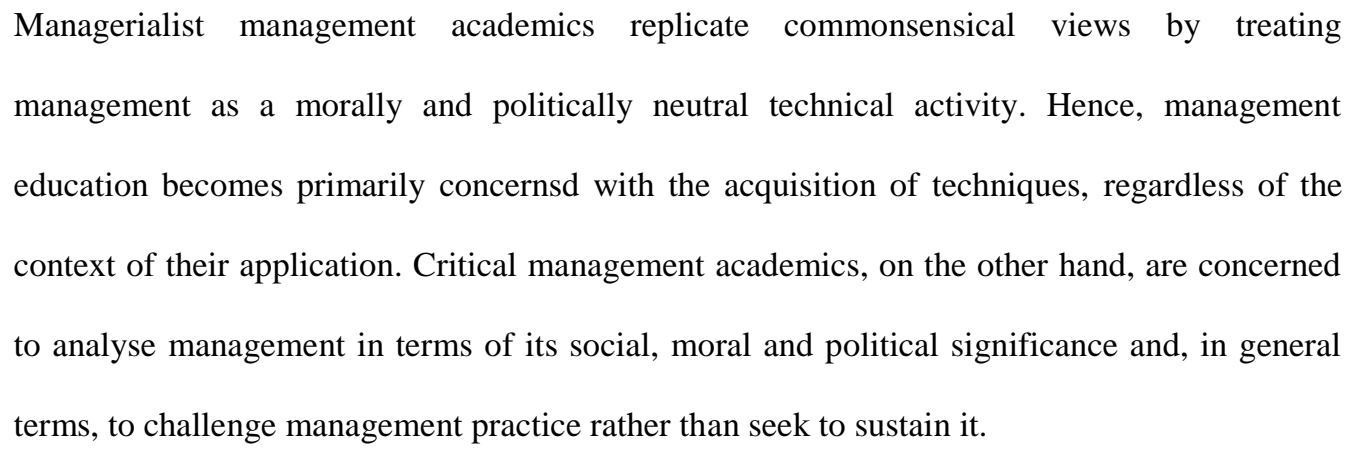

This requires a fundamental shift away from prevalent competence based approaches towards an approach that is more nuanced, reflective and critical. Such a perspective resonates with Schon's (1983) reflection-in-action and Mintzberg's (1975) ten roles of managers 'trying to make sense of the unique phenomena before them, testing their intuitive understandings and reformulating their questions' (Skinner, Tagg and Holloway 2004).

Helen Gunter (2005: 16) has been influential in redirecting the focus of the theoretical literature towards a more situated and purposive epistemology of educational leadership, that is, "what field members know and need to know, what is worth knowing, how they know and practice that knowing and who does the knowing.' In this formulation, nothing can be taken for granted, power relationships are exposed and open to question and critique, and strategies, positions and alignments become a proper focus for analysis and research. She goes on to make the important point that there is generally a normalisation of leaders and leadership, arising from their privileged social, economic and political status, such that much occurring in the field is taken for granted by field members who may be reluctant to question, still less challenge the status quo. This may go far to explain the widespread and long held view about the lack of impact of research in leadership and management upon management practice (eg Porter and McKibbin 1988, Mintzberg and Gosling 2002, Baldwin et al 2011). Asking critical, practical and positional questions is an ethical pursuit around which we are able to build a model of leadership which carries both moral authority and practical utility. 
However a challenge or change project requires a direction or purpose. For this I am proposing that in postcompulsory education institutions, which are after all archetypal learning organisations, we conceptualise critical practice leadership as leading learning. As Senge (1990: 340) puts it:

The new view of leadership in learning organizations centres on subtler and more important tasks. In a learning organization, leaders are designers, stewards and teachers. They are responsible for building organizations where people continually expand their capabilities to understand complexity, clarify vision, and improve shared mental models - that is, they are responsible for learning.

Leadership of learning is a powerful way to reconnect management and leadership with research. In this context, practitioner enquiry will recommend itself, as Coleman (2007: 483-4) has argued, as 'a more politicized form of research, as its underlying aim involves achieving change rather than simply studying an issue for its own sake'(Coleman and Lumby, 1999: 18).

This brings us to a model of critical practice leadership that is far from technical / rational. Critical practice leadership stands in contradistinction to the field of educational management studies, in which '(e)ducation as commodity requires to be 'packaged', 'delivered' and 'marketed' as efficiently as possible in the new pedagogical regimes', and where 'the discourse, assumptions and ideology of management has begun to dominate the language, consciousness and actions of many of those working within the education sector' (Grace 2000: 234). It is a model that challenges the status quo, exists to bring about change and improvement, and takes moral responsibility for learning and values. The importance of recognizing values in leadership is not only that in organizations '(i)ndividuals hold certain ideas and value-preferences which influence how they behave and how they view the behavior of other members' (Bush 1995: 130), but also that in organizations values interact dynamically with structure and culture, such that the formal structures and processes of an organization 'are themselves cultural artefacts' (O’Neill 1994: 103). As Lumby (1999: 64) comments:

The representations of structure reflect current norms and values and can be amended to reflect the direction of cultural change. Modifications in structure may also in themselves shift the 
norms and values of the organization. Changes in structure may therefore both follow and foreshadow cultural change.

There is no alternative for post compulsory education than to establish an ethical basis for leadership. Jameson (2006: 71) has graphically described the process of ethical fading (Tenbrunsel and Messick 2004) taking place in the sector: the self interested slippage in moral standards that can occur in leaders who believe, on the one hand, that they are holding moral principles, while simultaneously carrying out a range of unethical practices on the other.

Most importantly, critical practice leadership places learning and the learner at its heart and decisions are guided and evaluated in light of how they do or do not advance learner interests. What is being proposed here is not some idealistic, unrealistic prescription for leaders to act altruistically. As Surie and Ashley (2008: 16) have pointed out, 'organisational performance over the long term may be difficult to achieve without earning the trust of stakeholders'. There are other practical benefits. The approach allows for what Bolman and Deal (1984) have termed 'conceptual pluralism' utilising a variety of theoretical approaches to leadership, selecting and adapting these to meet particular contexts. This brings the benefit of enabling the leader to respond flexibly, reflexively and proactively to reforms, trends and events and to design strategies to be effective in the changing and challenging context of post compulsory education. This eclecticism, grounded in a values framework - that de minimus insists that a leader should do no harm - provides a robust model for leadership education, since it can embrace any of the many different leadership philosophies, approaches and styles currently in use (eg distributed, transformational, sustainable, to name but three). This is enormously helpful, since the small amount of empirical research done on educational leaders in post-compulsory education reveals that no one style or approach is followed by leaders of successful institutions (Lumby et al 2005).

Critical practice leadership embracing the notion of leadership of learning is an antedote to unethical and uncoupled leadership, since it can reconnect leaders with their career route and histories as teachers, lecturers and education professionals. At the same time, it reconnects with the fundamental purpose of an educational institution, to bring about change and advancement through educational endeavour and achievement. Leaders of learning will embrace research as an opportunity to identify the important problems of our time and prepare strategies to address these, question assumptions and seek an ethical values base for their own actions and those of others they lead, seek to 
place learning and the common good at the heart of institutional strategy such that their organisations are not selfserving but further the aspirations and attainment of their students and colleagues. They will be 'new theoreticians' or 'system thinkers in action' (Fullan 2005: x), who recognize that ' "making sense” requires theorizing' (Simkins 2005: 21), ready to act politically to limit and defeat the impact of marketisation, to protect their organisations for the benefit of generations to follow. Those with the privilege of educating tomorrow's leaders have a clear responsibility to awaken their students to the need to do no harm, and to inculcate the possibilities and potential of critical practice leadership, to transform perceptions of research and management and leadership practice itself.

\section{References}

Alvesson M and Deetz S (2000) Doing Critical Management Research. London: Sage.

Baldwin T, Pierce J, Joines R, and Farouk S (2011). The elusiveness of applied management knowledge: A critical challenge for management educators. Academy of Management Learning and Education, 10 (4): 583-605.

Ball S (2007) Education plc: Understanding Private Sector Participation in Public Sector Education. London: Routledge.

Bantock, G (1965) Education and Values. London: Faber and Faber.

Barnett R (2000) University knowledge in an age of supercomplexity. Higher Education 40 (4): 409-422.

Bennett R and Gill J (1978) The role of research in a regional management centre, Management Education and Development, December: 151-161.

Boal K and Hooijberg R (2001) Strategic Leadership Research: moving on. The Leadership Quarterly 11(4): 515549.

Bolman L and Deal T (1984) Modern Approaches to Understanding and Managing Organizations. San Franciscio: Jossey-Bass. 
Bourdieu P (1990) In other words: essays towards a reflexive sociology. Stanford, CA: Stanford University Press.

Bush T (1995) Theories of Educational Management $2^{\text {nd }}$ Edn. London: Paul Chapman.

Bush T (2011) Theories of Educational Leadership and Management, $4^{\text {th }}$ Edn., London: Sage.

Cochrane-Smith M and Lytle S (1998) Teacher research: the question that persists. International Journal of Leadership in Education: Theory and Practice 1 (1): 19-36.

Coleman A (2007) Leaders as researchers: supporting practitioner enquiry through the NCSL research associate programme. Educational Management, Leadership and Administration 35 (4): 479-497.

Coleman, M. and Lumby, J. (1999) 'The significance of site-based practitioner research in educational management' In: Middlewood D, Coleman M and Lumby J (Eds) Practitioner Research in Education: Making a difference. London: Paul Chapman Publishing. pp. 1-19.

Costley C, Elliott G, and Gibbs P (2010) Doing Work Based Research: Approaches to enquiry for insiderresearchers. London: Sage.

Crossley M. and Hall V (1994) 'Introduction: International perspectives on research training and educational management' in M Crossley and V Hall (Eds.) Research Training and Educational Management: International Perspectives. Bristol: Bristol Papers in Education, pp. 3-12.

Day C, Harris A and Hadfield M (2001) Challenging the orthodoxy of effective school Leadership. International Journal of Leadership in Education 4 (1): 39-56.

Deem R, Hillyard S and Reed M (2007). Knowledge, Higher Education, and the New Managerialism: The changing management of UK universities. Oxford: Oxford University Press.

Dempster N (2009) 'What do we know about leadership?’ In MacBeath J and Dempster N Connecting Leadership and Learning: principles for practice. London: Routledge, pp. 20-31.

Elliott G (1996) Educational management and the crisis of reform in further education. Journal of Vocational Education and Training 48 (1): 5-23. 
Elliott G (2012) Policy, performativity and partnership: an ethical leadership perspective . Research in PostCompulsory Education 17 (4): 423-433.

Elliott G and Crossley M (1994) Qualitative research, educational management and the incorporation of the further education sector. Educational Management and Administration 22(3): 188-197.

Elliott J (1991) Action Research for Educational Change. Milton Keynes: Open University Press.

Esland G (1996) Knowledge and nationhood: the new Right, education and the global market. In: Avis J, Bloomer M, Esland, G et al Eds) Knowledge and Nationhood: Education, Politics and Work. London: Cassell, pp. 11-39.

Feyrabend P (1975) Against Method: Outline of an anarchistic theory of knowledge. London: New Left Books.

Finch J (1986) Research and Policy: The uses of qualitative methods in social and educational research. London: Falmer.

Foskett N, Lumby J and Fidler B (2005) Evolution or extinction? Educational Management, Administration and Leadership 33(2): 245-253.

Freire P (1998) Pedagogy of Freedom: Ethics, Democracy, and Civic Courage. Lanham: Rowman and Littlefield.

Fullan M (1998) Leadership for the 21st Century: Breaking the Bonds of Dependency. Educational Leadership 55(7): 6-10.

Fullan M (2005) Leadership and Sustainability: System thinkers in action. Thousand Oaks, CA: Corwin Press.

Galton M (2000) Integrating Theory and Practice: Teachers' Perspectives on Educational Research. ESRC teaching and Learning Research Programme, First Annual Conference, Available at: http://www.leeds.ac.uk/educol/documents/00003247.htm (Accessed 5th February 2013).

Garfinkel H (1984) Studies in Ethnomethodology, Oxford: Blackwell [1967].

Gibbons M, Limoges L, Nowotney H, Schwartman S, Scott P, and Trow M (1994) The New Production of Knowledge: The dynamics of science and research in contemporary societies. London: Sage. 
Gill J and Johnson P (1997) Research Methods for Managers, 2nd Edn., London: Paul Chapman.

Gill R (2002) Change management - or change leadership? Journal of Change Management 3 (4): 307-318.

Gleeson D and Shain F (1999) By Appointment: Governance, markets and managerialism in further education. British Educational Research Journal 25(4): 545-61.

Gorard, S (2005) Current contexts for research in educational leadership and management. Educational Management, Administration and Leadership 33(2): 155-164.

Grace G (2000) Research and the Challenges of Contemporary School Leadership: The contribution of critical scholarship. British Journal of Educational Studies 48(3): 231-247.

Greenfield T (1991) Re-forming and re-valuing educational administration: Whence and when cometh the phoenix? Educational Management and Administration 19(4): 200-218.

Greenfield T (1993) The decline and fall of science in educational administration. In T Greenfield and P Ribbins (eds) Greenfield on Educational Administration: Towards a Humane Science. London: Routledge, pp. 199-228.

Grey C (2001) Re-imagining relevance: a response to Starkey and Madan. British Journal of Management 12 (Special Issue): S27-32.

Grey C and Mitev N (2004) Management Education: a polemic. In: Grey C and Antonacopoulou E (eds) Essential Readings in Management Learning. London: Sage, pp. 151-166.

Gunter H (2005) Conceptualising research in educational leadership. Educational Management, Administration and Leadership 33(2): 165-180.

Halliday J (1996) Values and further education. British Journal of Educational Studies 44 (1): 66-81.

Hargreaves A and Fink D (2006) Sustainable Leadership. San Francisco,CA: Jossey-Bass. 
Hargreaves D (1996) Teaching as a Research-Based Profession: possibilities and prospects. Teacher Training Agency Annual Lecture. London: Teacher Training Agency.

Hodgkinson C (1991) Educational Leadership: The Moral Art. New York: SUNY Press.

Hutchinson B (1995) Staff appraisal: personal, professional and organisational development. Educational Management, Adminsitration and Leadership 23(1): 47-57.

Hutchinson B (1996) Work, autonomy and democracy: competence in what? Curriculum Studies 4(1): 67-90.

Hutchinson B (1998) Learning action research and managing educational change - improvement in careers education. Educational Management, Administration and Leadership 26(4): 379-393.

Jackall R (1988) Moral Mazes: The World of Corporate Managers. Oxford: Oxford University Press.

Jameson J (2006) Leadership in Post Compulsory Education: Inspiring leaders of the future. Abingdon: David Fulton.

Kant E (1997) Critique of Practical Reason. Cambridge: Cambridge University Press [1788].

Lewin K (1952) Field theory in social science: Selected theoretical papers by Kurt Lewin. London: Tavistock.

Lingard B and Christie P (2003) Leading theory: Bourdieu and the field of educational leadership. An introduction and overview to this special issue. International Journal of Leadership in Education: Theory and Practice 6(4): $317-333$.

Lumby J (1999) Transforming structures and cultures. In: D Middlewood, M Coleman and J Lumby Practitioner Research in Education: Making a Difference. London: Paul Chapman, pp. 64-80.

Lumby J, Harrs A, Morrison M, Muijs D and Sood, K (2005) Leadership, Development and Diversity in the Learning and Skills Sector. London: LSRC. 
Lumby J and Tomlinson H (2000) Principals Speaking: managerialsm and leadership in further education. Research in Post-Compulsory Education 5(2):139-51.

McIntyre A (1981) After Virtue London: Duckworth.

Mintzberg H (1975) The manager's job: folklore and fact. Harvard Business Review July-August: 49-61.

Mintzberg H and Gosling J (2002) Educating managers beyond borders. Academy of Management Learning and Education 1 (1): 64-76.

Moore A, George R and Halpin D (2002) The developing role of the headteacher in English schools: management, leadership and pragmatism. Educational Managemenmt and Administration 30(2): 175-88.

Northouse P (2004) Leadership Theory and Practice. $3^{\text {rd }}$ Edn. London: Sage.

O’Neill J (1994) Organisational structures and cultures. In T Bush and J West-Burnham (Eds) Principles of Educational Management. Harlow: Longman, pp. 98-119.

Peters T (1989) Thriving on Chaos. London: Pan.

Porter L and McKibbin L (1988) Management Education and Development: Drift or thrust into the $21^{\text {st }}$ century? New York: McGraw Hill.

Randle K and Brady N (1997) Further Education and the New Managerialism. Journal of Further and Higher Education 21(2): 229-39.

Schon, D (1983) The Reflective Practitioner: How professionals think in action. London: Temple Smith.

Senge P (1990) The Fifth Discipline. London: Doubleday.

Sergiovanni T (1992) Moral Leadership: Getting to the Heart of School Improvement. San Francisco: Jossey-Bass.

Shavelson R, Phillips D, Townes L and Feuer M (2003) On the science of education design studies. Educational Researcher 32 (1): 25-8.

Simkins T (2005) Leadership in Education: 'What works' or 'What makes sense'? Educational Management, Administration and Leadership 33(1): 9-26. 
Skinner D, Tagg C, and Holloway J (2004) Managers and research: the pos and cons of qualitative approaches. In Grey C and Antonacopoulou (eds) Essential Readings in Management Learning. London: Sage, pp. 386-403.

Smith S (2013) Speech to British Council Conference, Tokyo, reported in The Guardian, 22 ${ }^{\text {nd }}$ January, p.32.

Starkey K and Madan P (2001) Bridging the relevance gap: aligning stakeholders in the future of management research. British Journal of Management 12: 3-26.

Stenhouse L (1975) An Introduction to Curriculum Research and Development. London: Heinemann.

Strain M (2009) Some ethical and cultural implications of the leadership 'turn' in education: on the distinction between performance and performativity. Educational Management Administration \& Leadership 37(1): 67-84.

Sumantra G (2005) Bad management theories are desctroying good management practices. Academy of Management Learning and Education 4(1): 75-91.

Surie E and Ashley A (2008) Integrating pragmatism and ethics in entrepreneurial leadership for sustainable value creation. Journal of Business Ethics 81(1): 235-246.

Tenbrunsel A, and Messick D (2004) Ethical fading: The role of self deception in unethical behavior. Social Justice Research 17(2): 223-236.

Tooley J and Darby D (1998) Educational Research: a critique. London: OFSTED.

Twyman P (1985) 'Management and Leadership in further education.' In M. Hughes, P. Ribbins and H. Thomas (Eds.), Managing Education: The System and the Institution, Eastbourne: Holt, Rinehart and Winston, pp. 325343.

Watson T (1994) In Search of Management. London: Routledge.

Weick K (1979) The Social Psychology of Organizing. $2^{\text {nd }}$ Edn. Reading, MA: Addison-Wesley.

Wheatley M (1994) Leadership and the New Science. San Francisco: Berrett-Koehler Publications Inc. 
Whiltley R (1984). The fragmented state of management studies: reasons and consequences. Journal of Management Studies 21 (e): 331-48.

Whitehead A (1962) The Aims of Education and other essays. $2^{\text {nd }}$ Edition. London: Ernest Benn. 